\title{
Study of Electromagnetic Effects of IH Cooker on Xenopus Laevis
}

\author{
A. Chuman, A. Nuruki, S. Tsujimura, and K. Yunokuchi \\ Department of Bioengineering, Kagoshima University, koorimoto, kagoshima-shi 890-0065, Japan
}

\begin{abstract}
The purpose of this study was to clarify what effect electromagnetic fields had on living bodies. We experimented on Xenopus laevis as an individual. We compared the lengths of tails of frogs exposed to the electromagnetic field $(20 \mathrm{kHz})$ of an IH cooker and a Merritt coil to the tail lengths of sham-exposure frogs. We experimented by changing the exposure time and strength of the electromagnetic field. The results for the present study revealed that an increase in the total daily exposure of Xenopus laevis to an electromagnetic field will speed up metamorphosis.
\end{abstract}

Key words: electromagnetic field, frog (Xenopus laevis), IH cooker

\section{電磁調理器の電磁界によるアフリカツメガエルへの作用に関する考察}

\author{
中馬亜津沙・塗木淳夫・辻村誠一・湯ノ口万友 \\ 鹿児島大学 工学部 生体工学科, 鹿児島市郡元 $\bar{T} 890-0065$
}

\section{1. はじめに}

近年, 電磁界を用いた機器は私たちの生活に欠かせないも のとなっている. 携帯電話や誘導加熱機器などの普及は同時 に電磁界の安全性などに対する関心をもたらしている．電磁 界の作用については 1979 年の高圧送電線に関する報告 1)を 初めとして, 生体への作用に対する定量的評価や作用機序の 解明を目的に現在も多くの研究が進められている. ${ }^{2)}$ 3) しかし, 家庭用機器から生じる中間周波数帯の電磁界による生体一 の影響に関する研究についてはほとんど報告されていない.

本研究は実際の曝露条件に近づけ, また生体の恒常性を考 慮して, 生物個体を用いて実験を行った。実験は, 生物個体 としてカエルを使用し，生体を維持するための機能である細 胞分裂や細胞死（アポトーシス）が活発に働いているカエル の変態時期に着目した. 作用の検討方法として受精卵時から 電磁界曝露を行ったカエルと電磁界曝露を行っていない力 エルの尾長の変化を用いて変態時期の比較を行った. 電磁界 曝露は, 近年家庭に普及しつつある電磁調理器とメリットコ イルによる電磁界を用いて行った。

本研究では電磁界の生体への作用を解明する手がかりと して, 電磁界がカエルの変態（成長）に与える作用を明らか にすることを目的としている.

\section{2. 実験方法}

実験対象は, 飼育が容易であり, 年間を通じて産卵が可能 なアフリカツメガエルを用いた. アフリカツメガエルは同一 の親ガエルから抽出した受精卵を用い, 直径 $18 \mathrm{~cm}$ のビーカ 一内で $0.3 \%$ の生理食塩水 $1500 \mathrm{ml}$ 中において飼育した. 電 磁界曝露を行う際, 磁場影響と誘導電流による影響の両方を 検討するために導電体として生理食塩水により飼育した. 電
磁界曝露は, 電磁調理器 (誘導周波数 $19.76 \mathrm{kHz}$, 出力 $3 \mathrm{~kW}$ ) とメリットコイル（誘導周波数 $20 \mathrm{kHz}$ ) を用いて受精から 毎日 70 日間行った.

以後, 電磁調理器, メリットコイルを用いて曝露を行った 対象を IH 群, メリットコイル群と称する。 また，電磁界曝 露を行っていないカエルを比較対照として Control 群と称す る. アフリカツメガエルは IH 群, Control 群, メリットコ イル群に違いが現れないようビーカー内に 7 10 匹を飼育し, 1 日 1 回 $2 \mathrm{~g}$ のエサを与えた. Control, Exposure ともに同 室内で飼育し, 光の当たる時間帯, 光度などのコントロール は行っていない. ビーカー内の水温は, 室温を一定に保つこ とによりコントロールしている. 各ビーカー内の水温差は最 大 0.2 度である.

実験は, IH 群, メリットコイル群, Control 群の尾長の変 化を比較検討した.

\section{2-1. 電磁調理器による電磁界曝露方法}

Fig.1 に電磁調理器による電磁界曝露方法を示す. 電磁調 理器による電磁界の磁束密度測定については, 国際基準であ る IEC 62233 によって定義されている. 4)電磁調理器 (IH) は，右側コンロに IEC 62233 に基づいた直径 $180 \mathrm{~mm}$ の水 を張った鍋をのせ, 最大出力 $3 \mathrm{~kW}$ で動作させ使用した. IEC 62233 に定義されている磁束密度の測定距離は機器から 300 $\mathrm{mm}$ としているが, 本実験における曝露は, 電磁調理器周辺 で最も電磁界強度の強い場所である右側コンロの前方端に ビーカーを設置して行った. ビーカー下面は電磁調理器の天 板の高さとし, ビーカーの側面が電磁調理器の端になるよう に設置した. 電磁調理器による電磁界は Fig. 4(a)のように時 間周波数 $20 \mathrm{kHz}$ の電磁界が $120 \mathrm{kHz}$ の周波数によって振幅 変調されたような波形となっている．また，発生源からの距 離が離れるにつれ急激に減衰するためビーカー内でも電磁 
界分布が異なり, 個々のカエルにより曝露量は変化すること が考えられる. 電磁界は, 電磁調理器にもつとも接近した部 分で最大強度は $17 \mu \mathrm{T}$ となる. Fig. 2 は天板から $110 \mathrm{~mm}$ の高さでの磁界強度を示している. 最大で 10 12.5 $\mu \mathrm{T}$ の強 度であるが, ビーカー後方に位置する $100 \mathrm{~mm}$ から $200 \mathrm{~mm}$ の位置では, 磁場強度は 0 2.5 $\mu \mathrm{T}$ まで減衰している.

曝露時間は受精日から毎日 70 日間, 短時間曝露である 90 分/日または長時間曝露である 5 時間/日とした。

\section{2-2. メリットコイルを用いた電磁界曝露方法}

Fig. 3 にメリットコイルを用いた電磁界曝露方法を示す. メリットコイルによる電磁界の誘導周波数は電磁調理器と 同様の $20 \mathrm{kHz}$ とし, メリットコイルによる電磁界は, Fig. 4(b) のように振幅一定であり, 空間的にも均一であるため対 象は常に一定強度の電磁界に曝露される. 本実験においてメ リットコイルの磁場強度と曝露時間は, 電磁調理器の最大磁 場強度である $17 \mu \mathrm{T}$ による短時間曝露, 長時間曝露に加え $5 \mu \mathrm{T}, 50 \mu \mathrm{T}$ の短時間曝露の計 4 種類とした.

\section{2-3. 計測システム}

実験対象はカメラを用いて毎日画像として記録した。記録 は, 受精日の 40 日後から 70 日後までの 30 日間毎日行った.

撮影した画像は画像解析ソフト（NI Vision Assistant）を 用いて対象の尾長を測定した. 尾長はオタマジャクシの総排 出口から尻尾の先端までとし, 尻尾を複数の直線で近似しそ れらの長さの積分值とした（Fig. 5).

両生類は, 幼生型（オタマジャクシ）時に, ある発育段階に 達すると, 体形, 体制, 生理機能に急激な変化が起こり成体

(a)

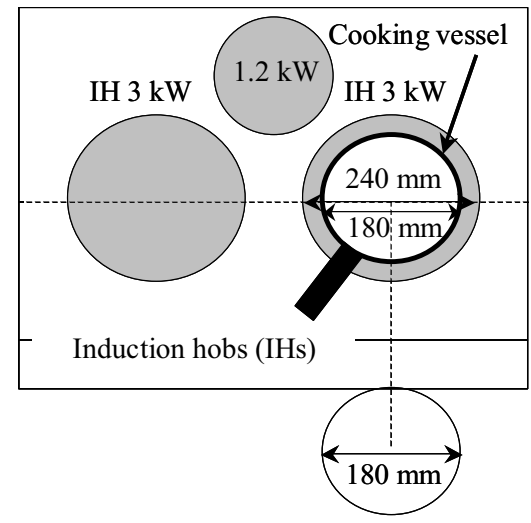

(b)

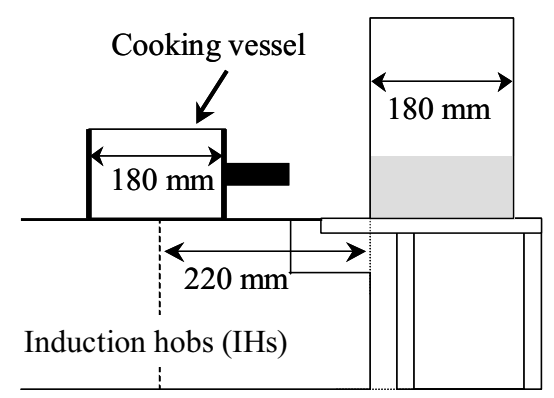

Fig. 1 Exposure to electromagnetic field using IH Cooker. (a) : top view and (b) : side view.
形（カエル）となる. 一般的に，この幼生型から成体形への 転換を変態としている ${ }^{5)}$ が，本論文では便宜上，オタマジャ クシの尻尾の収縮開始から完全になくなるまでを変態時期 と呼ぶ.

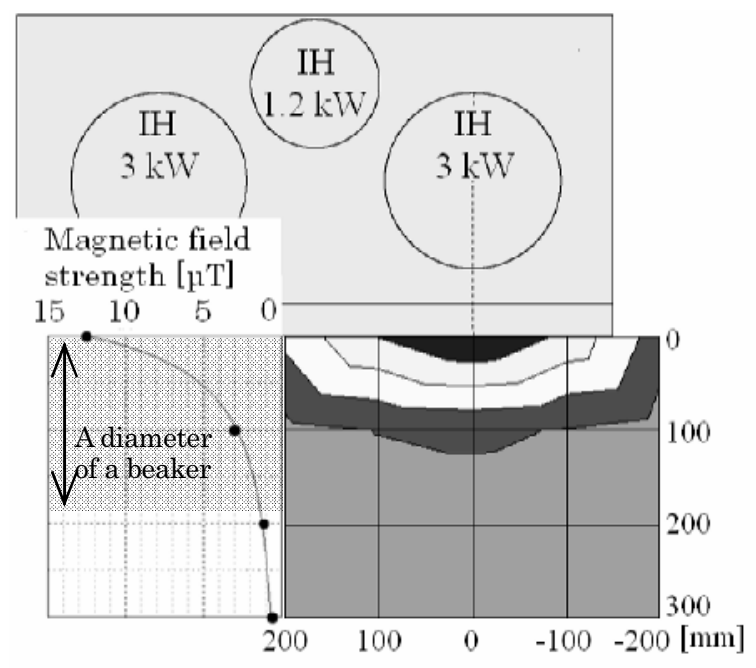

$\square 0 \sim 2.5 \square 2.5 \sim 5 \square 5 \sim 7.5 \square 7.5 \sim 10 \square 10 \sim 12.5[\mu \mathrm{T}]$

Fig. 2 Magnetic field strength of IH Cooker.

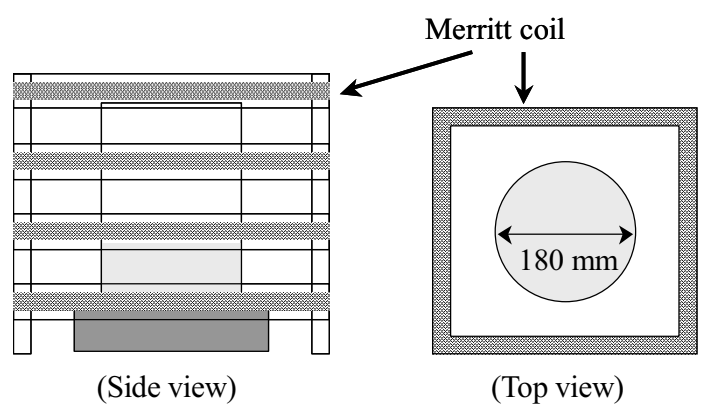

Fig. 3 Exposure to electromagnetic field using Merritt coil.

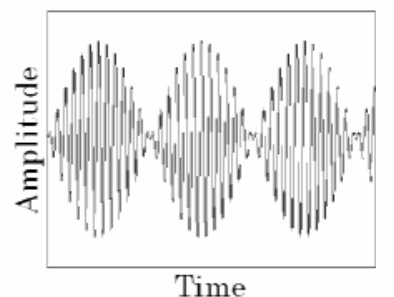

(a) IH Cooker

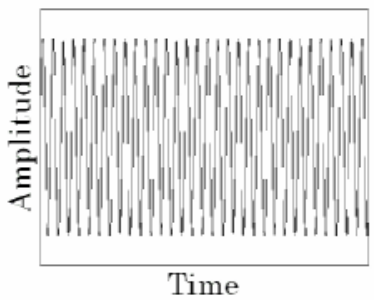

(b) Merritt coil
Fig. 4 Electromagnetic waveform.

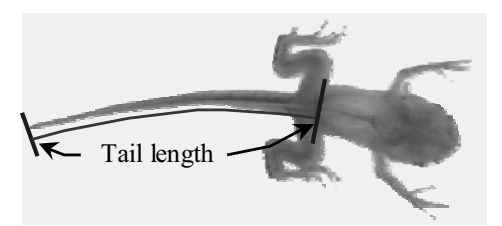

Fig. 5 Definition of tail length. 


\section{3. 実験結果}

\section{3-1. 電磁調理器の電磁界によるカエルの変態（成長） の影響 一曝露時間による検討一}

Fig. 6 に電磁調理器により短時間曝露 (90 分), 長時間曝 露（5 時間）を行ったカエルの尾長の変化を示す. 尾長の変 化は，個体差が大きいため，中央值によって示している．電 磁調理器による 5 時間曝露は 90 分曝露に比べ尾の収縮開始 が早まった。

電磁調理器による電磁界強度は, ビーカー内の位置によっ てばらつく（図 2). 曝露時間の延長は, 最大電磁界強度に曝 露される機会が多くなることを示し, 曝露時間が長いほど変 態（成長）により影響を与えていると考えられる.

\section{3-2. 電磁調理器とメリットコイルの電磁界によるカエルの 変態 (成長) への影響の比較}

Fig. 7 に control, 電磁調理器の長時閒曝露 (5 時間), メリ ットコイルの短時間曝露 (90 分) を行ったカエルの尾長の中 央值を示す. 電磁調理器による 5 時間曝露, メリットコイル による 90 分曝露は control 群に対して変態開始が早くなって いる，これは電磁界曝露により，成長が促進されたとも考え ることができる. また, 電磁調理器による 5 時間曝露とメリ ットコイルによる 90 分曝露は, 曝露時間が異なるにも関わ らず，カエルの変態が control 群に対して同程度早くなって いる. これは電磁調理器による電磁界の曝露量がばらつくの に対して, メリットコイルの強度が電磁調理器の最大強度を 保っているためだと考えられる.

実験結果 3-2 より, 変態（成長）に対してメリットコイル においても電磁調理器による曝露と同様の影響が見られた. メリットコイルによる電磁界は, ビーカー内において常に一 定の強度を保つことができる，そのため，実験 3-3，3-4 にお いて曝露時間と曝露強度を変化させたときのカエルの変態 （成長）への影響を検討した.

\section{3-3. メリットコイルの電磁界によるカエルの変態 (成長) ヘ の影響 一電磁界強度による検討一}

Fig. 8 に電磁界強度を変化させた場合のカエルの成長（変 態）への影響に関する結果について示寸. 低強度である $5 \mu$ $\mathrm{T}$ での曝露に対して $50 \mu \mathrm{T}$ の曝露は尾の収縮開始が早くなつ ていることから, 電磁界曝露の強度が強いほどカエルの変態 (成長) に影響を与えている．変態による急激な尾の変化が 見られた受精日の 51 日目から 57 日目までの尾長については 統計的に有意 $(\mathrm{P}<0.05)$ な差が確認された.

Fig. 9 は, Fig. 8 において示したカエルの尾長の中央值に 個々のデータを加えたグラフである. それぞれの群は個体差

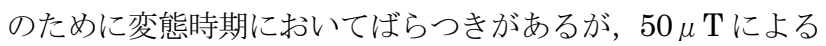
曝露群は変態時期が早くなっていることが分かる.

\section{3-4. メリットコイルの電磁界によるカエルの変態 (成長) へ の影響 一曝露時間による検討一}

Fig.10 にメリットコイルにより短時間曝露 (90 分), 長時間 曝露 (21 時間) を行ったカエルの尾長の変化の中央值を示す.
メリットコイルによる 21 時間曝露は 90 分曝露に比べ尾の収 縮開始が早まった。つまり, 成長が早まったことが分かる.

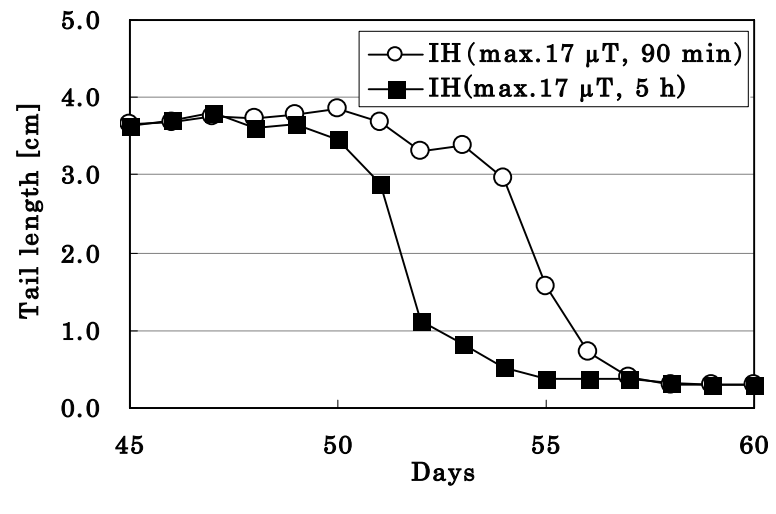

IH (90 min $) \mathrm{n}=19, \quad$ IH $(5 \mathrm{~h}) \mathrm{n}=8$

Fig. 6 Change in tail length of Xenopus laevis.

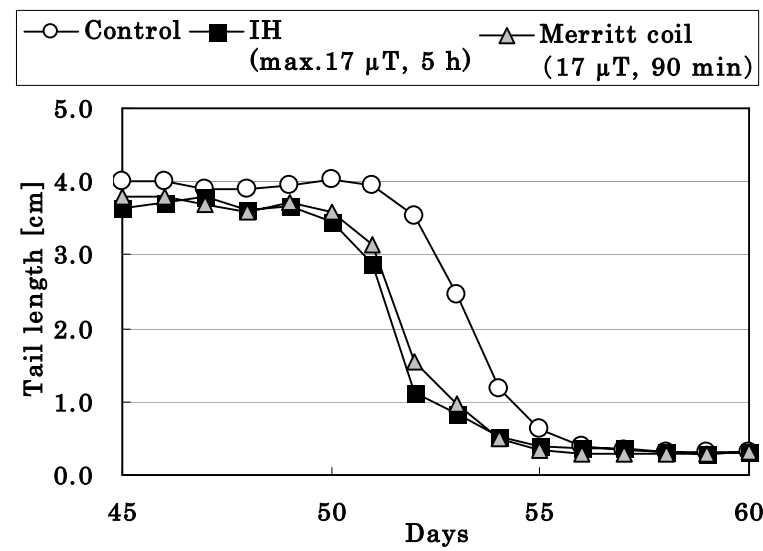

Control $n=17$, IH (5 h) n= 8, Merritt coil (90 min) $n=8$

Fig. 7 Change in tail length of Xenopus laevis.

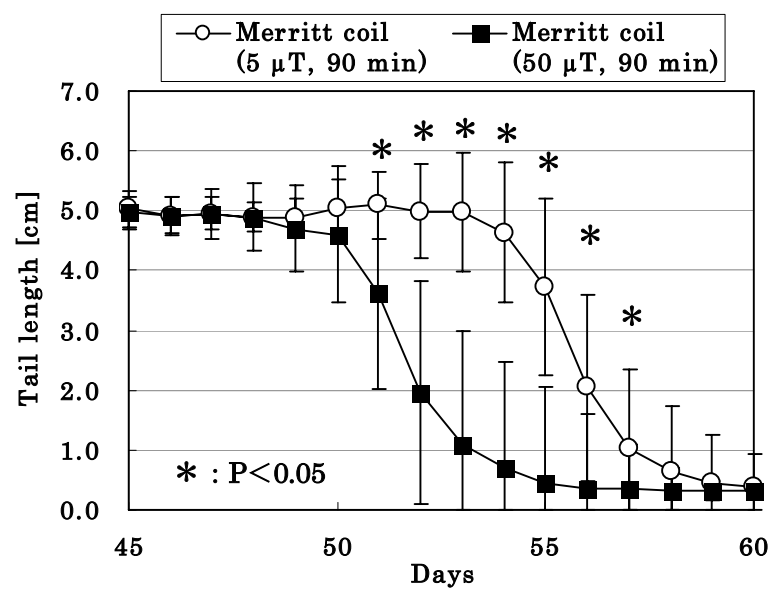

Merritt coil $(5 \mu \mathrm{T}) \mathrm{n}=15$, Merritt coil $(50 \mu \mathrm{T}) \mathrm{n}=16$ Error bar: Median Absolute Deviation (MAD)

Fig. 8 Change in tail length of Xenopus laevis. 


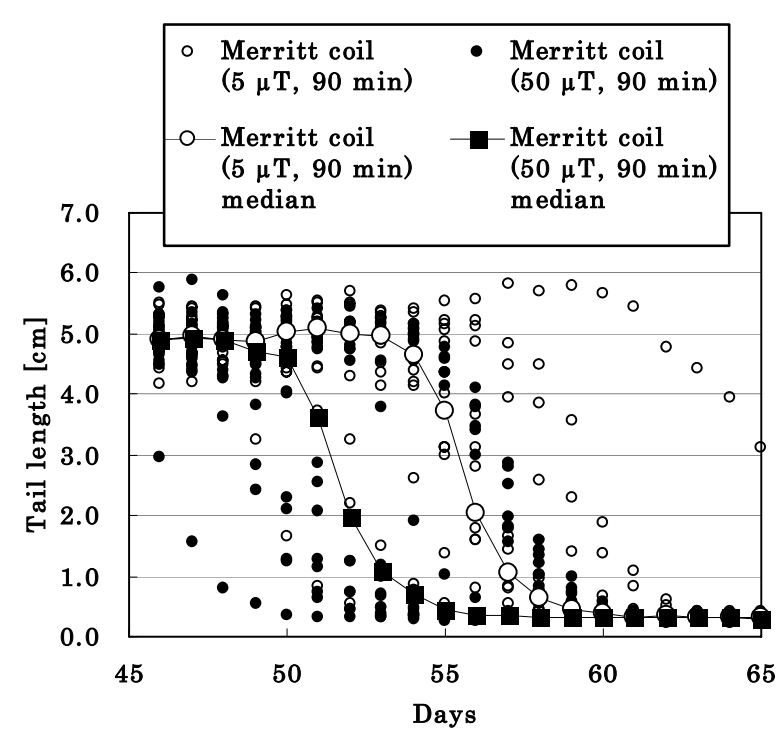

Merritt coil $(5 \mu \mathrm{T}) \mathrm{n}=15$, Merritt coil $(50 \mu \mathrm{T}) \mathrm{n}=16$

Fig.9 Change in tail length of Xenopus laevis.

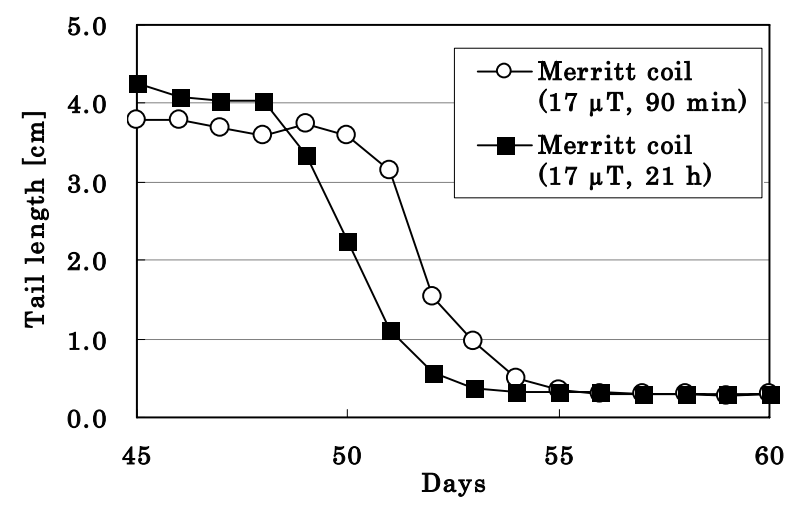

Merritt coil $(17 \mu \mathrm{T}, 90 \mathrm{~min}) \mathrm{n}=8$ Merritt coil $(17 \mu \mathrm{T}, 21 \mathrm{~h}) \mathrm{n}=8$

Fig. 10 Change in tail length of Xenopus laevis.

\section{4. 考察}

電磁調理器による電磁界曝露実験では 90 分曝露に対して 5 時間曝露では変態 (成長) が早くなったことから, 曝露時 間が長いほど変態 (成長) により影響を与えると考えられる. 電磁調理器による曝露は Fig.1 に示すように行ったが，電磁 調理器による電磁界は距離による減衰が大きく, 対象への曝 露がばらつくため, 曝露量も低下する.

そこで，電磁界強度を任意に選択できるメリットコイルに よる電磁界曝露実験を行い，90 分曝露に対して 21 時間曝露 では変態（成長）が早くなる同様の結果が得られた。また， メリットコイルによる電磁界の強度を変化させた場合, 電磁 界強度の強い $50 \mu \mathrm{T}$ での曝露は $5 \mu \mathrm{T}$ での曝露に対してカ エルの変態 (成長) が早くなった。図 11 は, 磁場曝露総量 (磁場と時間の積)に対する変態終了日の変化を示す. Group $\mathrm{A}$ は電磁調理器とメリットコイルを用いて曝露時間を変化さ せたものであり, Group B はメリットコイルを用いて曝露強
度を変化させたものである，先述したように，親ガエルが異 なるとカエルの成長には違いが現れる. そのため, Group A と Group B 閒では, 比較対照である Control 群についても変 態終了日が異なっている.

図 11 より, $20 \mathrm{kHz}$ での電磁界曝露はカエルの 1 日の曝露 総量が増加するにしたがってより変態（成長）への影響を与 えると考えられる.

生体の成長に関しては温度の影響が大きいと考えられる. 本実験において, 電磁調理器により電磁界曝露を行った場合, $\mathrm{IH}$ 動作時の鍋水の沸騰による放射熱より IH群のビーカーは Control 群のビーカーに対して 0.2 度程度上昇している. し かし, 動作による温度上昇が 0.1 度程度であるメリットコイ ルにおいても, 変態 (成長) が早くなったことから, 変態 (成 長）への作用は温度だけではないと考えられる，そのため， 今回の電磁調理器による 5 時間曝露, メリットコイルによる $17 \mu \mathrm{T}$ の 90 分, 21 時間曝露, $50 \mu \mathrm{T}$ の 90 分曝露におい て変態 (成長) が早まったのは, 温度以外の別の要因と考え られる。

一般的に両生類の成長と変態は, 主として内分泌系によっ て調整されており, 特に変態は甲状腺ホルモンによって制御 されている，6)そのため，電磁界はカエルの内分泌系に作用 することで変態（成長）に関与していると考えられ，そのな かでも甲状腺ホルモンまたはその分泌に関わる他のホルモ ンに関与している可能性がある.

本実験では，電磁調理器の電磁界による短時間曝露におい て変態 (成長) への影響を明らかにすることはできなかった. しかし, 電磁調理器の電磁界の減衰を考慮し, 常に強度の高 い部分で曝露されるような環境下で実験を行った場合，短時 間の曝露において生体への影響が生じる可能性も考えられ る.

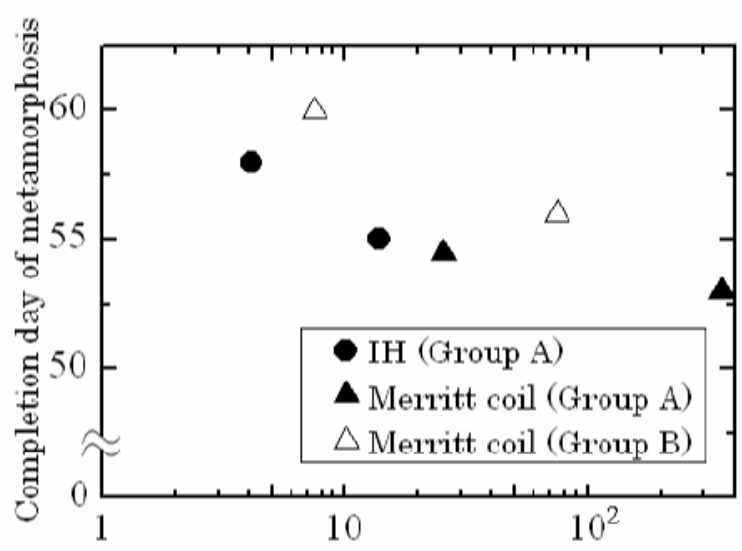

Total amount of exposed magnetic field [ $\mu \mathrm{T} \cdot \mathrm{h}]$

Fig. 11 Completion day of metamorphosis. 


\section{5. まとめ}

本実験では，電磁界の生体への作用の検討としてアフリカ ツメガエルに受精卵時から電磁界曝露を行った場合と行っ ていない場合の変態（成長）への作用を明らかにすることを 目的とした.

電磁調理器による電磁界曝露では，曝露時間が長いほどカ エルの変態 (成長) が早くなった。 また，水温変化を伴わな いメリットコイルによる電磁界曝露により, 曝露時間が長く また電磁界強度が強いほど変態（成長）が早くなる傾向が見 られた.

謝辞 本研究を行うにあたり, 快くXenopus laevis の受精卵 を提供してくださった鹿児島大学理学部, 坂井雅夫教授に謝 意を示します.

\section{References}

1) Wertheimer. $\mathrm{N}$ and Leeper. E: Am. J. Epidemiology., 109, 273-284 (1979)

2) S. Lu, N. Lebda, S. M. Michaelson, and S. Pettit: Radiation Research., 101, 413-423 (1985).

3) J. M. Watson, E. A. Parrish, and C. A. Rinehart: Gynecologic oncology., 71, 64-71 (1998).

4) IEC (International Electro technical Commission): IEC 62233 , p. 51 (IEC, 2005)

5) H. Iwasawa, and M. Kuramoto: Doubutsu keitou Bunruigaku 9 no ge Ryouseirui 1 (in Japanese), p.193 (Yamanaka Syoten, Tokyo, 1997)

6) Nihon Hassei Seibutsu Gakkai: Hentai no Seibutsugaku (in Japanese), p. 227 (Iwanami Syoten, Tokyo, 1978).

2006 年 10 月 4 日受理, 2007 年 3 月 19 日採録 